\title{
Quality and bioactive compounds in fruit of foreign accessions of mango conserved in an Active Germplasm Bank ${ }^{1}$
}

\author{
Qualidade e compostos bioativos de frutos de acessos estrangeiros de mangueira \\ conservados em Banco Ativo de Germoplasma
}

\author{
Thalita Passos Ribeiro ${ }^{2 *}$, Maria Auxiliadora Coêlho de Lima ${ }^{3}$, Danielly Cristina Gomes da Trindade ${ }^{3}$, Francisco \\ Pinheiro Lima Neto ${ }^{3}$ e Nara Cristina Ristow ${ }^{3}$
}

\begin{abstract}
The aim of this study was to characterise the quality and levels of bioactive compounds in the fruit of 22 foreign accessions of the mango belonging to the Active Germplasm Bank of Embrapa Semiárido. Sixty fruits from each of the accessions: Florigon, Haden, 65, Irwin, M 13269, Momi-K, Scuper Many, Simmonds, Tommy Atkins, Van Dyke, Winter, Zill, Amrapali, Olour, Aplle DCG 406, Mon Amon DCG 407, Black Java, Kensington, Chené, Manila, Manzanillo and Maya, were harvested upon reaching physiological maturity, one half being analysed when harvested and the other half stored at ambient temperature $\left(25.4 \pm 2.9^{\circ} \mathrm{C}\right.$ and $\left.41 \pm 9 \% \mathrm{RH}\right)$ until ripe. The experimental design was completely randomised in a $22 \times 2$ factorial (accession $\times$ maturity stage), with three replications of ten fruits. The accessions Chene, Momi-K and Van Dyke stood out for their physical attributes: weight, length, diameter and firmness of pulp, and for their good post-harvest conservation. The accession Amrapali was different because of its high levels of soluble solids, total soluble sugars, starch, ascorbic acid and carotenoids, suggesting a high potential for insertion into a breeding program aimed at the quality of the mango.
\end{abstract}

Key words: Mango. Postharvest. Genetic resources. Vitamin C. Carotenoids.

RESUMO - O objetivo deste estudo foi caracterizar a qualidade e o teor de compostos bioativos dos frutos de 22 acessos estrangeiros de mangueira, pertencentes ao Banco Ativo de Germoplasma da Embrapa Semiárido. Sessenta frutos de cada um dos acessos Florigon, Haden, 65, Irwin, M 13269, Momi-K, Scuper Many, Simmonds, Tommy Atkins, Van Dyke, Winter, Zill, Amrapali, Olour, Aplle DCG 406, Mon Amon DCG 407, Black Java, Kensington, Chené, Manila, Manzanillo e Maya foram colhidos quando atingiram a maturidade fisiológica, sendo a metade analisada no dia da colheita e a outra metade armazenada, sob temperatura ambiente $\left(25,4 \pm 2,9^{\circ} \mathrm{C}\right.$ e $41 \pm 9 \%$ UR), para completar o amadurecimento. O delineamento experimental foi inteiramente casualizado, em fatorial $22 \times 2$ (acesso x estádio de maturação), com três repetições de dez frutos. Os acessos Chené, Momi-K e Van Dyke destacaram-se quanto aos atributos físicos peso, comprimento, diâmetro e firmeza da polpa e pela boa conservação pós-colheita. O acesso Amrapali diferenciou-se pelos elevados teores de sólidos solúveis, açúcares solúveis totais, amido, ácido ascórbico e carotenoides, sugerindo alto potencial para inserção em programa de melhoramento genético orientado para a qualidade da manga.

Palavras-chave: Manga. Pós-Colheita. Recursos genéticos. Vitamina C. Carotenoides.

\footnotetext{
*Autor para correspondência

${ }^{1}$ Recebido para publicação em 28/03/2012; aprovado em 15/10/2014

Pesquisa financiada pela Embrapa

2Departamento de Fitotecnia, Universidade Federal Rural do Semiárido, BR 101, Km 47, Mossoró-RN, Brasil, 59.625-900, thalita-passos@ hotmail.com ${ }^{3}$ Embrapa Semiárido, BR 428, Km 152, Caixa postal 23, Petrolina-PE, Brasil, 56.302-970, auxiliadora.lima@embrapa.br, pinheiro.neto@ embrapa.br, danielly.trindade@embrapa.br, ncristow@ hotmail.com
} 


\section{INTRODUCTION}

Brazilian mango production in 2010 was 1,197,694 tonnes, of which about 124,694 tonnes were exported, producing US\$119,929,762 in revenue. The main destinations were the Netherlands, the United States, Spain, the UK and Portugal, which received respectively 49, 20, 10, 7 and 5\% of the Brazilian exports (INSTITUTO BRASILEIRO DE FRUTAS, 2011; VALEXPORT, 2011).

Among cultivars, the most widely produced and exported by Brazil is still Tommy Atkins, which despite excellent fruit colouration, relative resistance to disease and acceptable post-harvest conservation, has a high susceptibility to floral malformation and internal breakdown, as well as fibres and only a slightly pronounced flavour, characteristics which have reduced its acceptance among foreign consumers (PINTO et al., 2002). Moreover, the predominance of any one cultivar over large areas increases the risk of phytosanitary problems or of oversupply, reducing business competitiveness, or even compromising its continuation (PINTO et al., 2005).

To prevent such serious consequences, it is important to introduce, evaluate and select species which offer innovative features to the market, as well as cultivars with characteristics that may strengthen the list of choices of parental groups, leading to the achievement of new genetic material (PINTO; PINHEIRO NETO; GUIMARÃES, 2011). Currently, action does not just focus on productivity, adaptation to environmental conditions or agricultural practices, but mainly on fruit quality, which has become a differentiating and determining element in breeding programs. Among the requirements related to quality are included sensory attributes connected to appearance (colour, size, shape, absence of defects), flavour (levels of soluble solids, titratable acidity) and aroma, as well as nutritional value (vitamin $\mathrm{C}$ content, carotenoids) and the health and physical integrity of the consumer (BRECHT; YAHIA, 2009).

Aiming to provide technical and scientific support to these initiatives, studies are being conducted in various regions to characterise mango cultivars (BERNARDESSILVA; LAJOLO; CORDENUNSI, 2003; GALLI et al., 2008; RUFINI et al., 2011). Many of these studies consider the physicochemical and chemical characteristics of the fruit. Under the conditions of the state of Minas Gerais, Ribeiro et al. (2007) emphasised that the Tommy Atkins, Palmer and Ubá cultivars displayed high levels of carotenoids, however the Ubá cultivar was also distinguished by its high levels of phenolic compounds and ascorbic acid.

Using this approach, the aim of this study was to characterise the quality and levels of bioactive compounds in the fruit of 22 foreign accessions of the mango, which are stored in the Active Germplasm Bank (AGB) of Embrapa Semiárido.

\section{MATERIAL AND METHODS}

The mango fruit originated at the AGB of Embrapa Semiárido, located in the Mandacaru Experimental Area in Juazeiro, in the state of Bahia ( $09^{\circ} 24$ ' $\mathrm{S}, 40^{\circ} 26^{\prime}$ ' W). Twenty-two accessions were evaluated, twelve from North America (Florigon, Haden, 65, Irwin, M 13269, MomiK, Scuper Many, Simmonds, Tommy Atkins, Van Dyke, Winter and Zill), two from India (Amrapali and Olour) two from Thailand (Aplle DCG 406 and Mon Amon DCG 407), two from Australia (Black Java and Kensington), one from Africa (Chené), one from the Philipines (Manila), one from Mexico (Manzanillo) and one from Israel (Maya). The Tommy Atkins cultivar was taken as the reference for the evaluations due to its economic importance.

The plants from the ABG were planted in 1994, and are grown on a Vertisol, at a spacing of $10 \mathrm{~m} \mathrm{x} 10 \mathrm{~m}$, and irrigated by micro-sprinkler. Agricultural treatments followed the recommendations for crops in the Vale do São Francisco.

During the 2008/2009 harvest, 60 fruits were uniformly collected for each accession when reaching physiological maturity, which is characterised by a change in skin colour to light green and by the beginning of softening. After collection, the fruits were transported to the Laboratory for Post-harvest Physiology of Embrapa Semiárido in Petrolina, in the state of Pernambuco. In the laboratory, half of the fruit from each accession was analysed at their current maturity stage, and the other half was stored at room temperature $\left(25.4 \pm 2.9^{\circ} \mathrm{C}\right.$ and $41 \pm$ $9 \% \mathrm{RH}$ ) until they ripened, when they were then analysed. It should be noted that storage at room temperature to complete ripening was not possible for the fruits of the Manila accession. Plants from that accession had low fruit yield and the advancement of maturation in some of the fruits meant that standardised harvesting at physiological maturity was not possible. Consequently for that case, only fruits that ripened on the plant were evaluated.

The variables analysed were: a) weight $(\mathrm{g})$ : obtained with a semi-analytic balance; b) longitudinal and transverse diameters (mm): obtained with calipers; c) pulp firmness (N): measured using an FT 327 manual penetrometer with a tip of $8 \mathrm{~mm}$ in diameter; d) presence of fibres: by subjective assessment (visual and tactile), considering absent, low and fibrous; e) colour of the skin and pulp: determined by digital colorimeter, using the attributes of luminosity (L), chroma (C) and hue (H) (RIBEIRO et al., 2009); f) titratable acidity (TA, \% citric acid): by titration with a solution of $0.1 \mathrm{~N}$ $\mathrm{NaOH}$ (ASSOCIATION OF OFFICIAL ANALYTICAL 
CHEMISTS, 1998); g) soluble solid content (SS, ${ }^{\circ}$ Brix): determined by direct reading with a digital refractometer with automatic temperature compensation (ASSOCIATION OF OFFICIALANALYTICAL CHEMISTS, 1998); h) total soluble sugar content (TSS, g $100 \mathrm{~g}^{-1}$ ), extracted in $80 \%$ ethanol and quantified using the anthrone reagent (YEMN; WILLIS, 1954); i) reducing sugars content (RS, g $100 \mathrm{~g}^{-1}$ ): extracted in water and determined with the method proposed by Miller (1959); j) starch content $\left(100 \mathrm{~g}^{-1}\right)$ : determined by acid hydrolysis (ASSOCIATION OF OFFICIAL ANALYTICAL CHEMISTS, 1998) and quantified from the released RS (Miller, 1959); k) vitamin C content (mg ascorbic acid $100 \mathrm{ml}^{-1}$ ): following a recommendation of the Association of Official Analytical Chemists (1998); 1) total carotenoids content (mg $\left.100 \mathrm{~g}^{-1}\right)$ : determined according to the method described by the Association of Official Analytical Chemists (1998). The number of days from harvest to the ripe stage were also evaluated, as indication of the perishability of the fruits of each accession under the storage conditions mentioned above.

The experimental design was completely randomised, in a $22 \times 2$ factorial (accession $\times$ maturity stage), with three replications consisting of ten fruits. The data were submitted to variance analysis and the means were compared by Scott-Knott test ( $\leq \leq 0.05)$. When interaction between factors was statistically significant, a breakdown of the accessions for each maturity stage was carried out (BANZATTO; KRONKA, 2006).

\section{RESULTS AND DISCUSSION}

As there was significant interaction between factors for all variables, this study demonstrated the existence of high genetic variability between accessions, influenced in a decisive way by their maturity stage.

Although not currently a criterion for mandatory disposal, since smaller fruits can be used for the domestic market, there are requirements as to the weight of mangoes for export, with priority being given to fruits of approximately $450 \mathrm{~g}$ (PINTO et al., 2002). Fruits from the accessions Tommy Atkins, Aplle DCG 406, Black Java, Chené, Kensington, Mon Amon, 65, Haden, Irwin, Momi-K and Zill (Table 1) all met this requirement. Galli et al. (2008) had already highlighted this attribute in the latter.

The relationship between length and diameter with fruit weight was confirmed in the Tommy Atkins accession, which showed an average of 103.69 and $97.81 \mathrm{~mm}$ for length and 90.07 and $78.76 \mathrm{~mm}$ for diameter at the two maturity stage respectively (Table 1). The accessions that were similar were the Chené, Manzanillo and Momi-K.
As to firmness, eight distinct groups were formed for fruit at physiological maturity, whose averages ranged from 57.22 to $123.58 \mathrm{~N}$ (Table 1). The Winter and Van Dyke accessions stood out as having more firmness when harvested. A second group was formed by the Momi-K, M-13269, Tommy Atkins and Aplle DCG 406 accessions, with a pulp firmness of more than $110 \mathrm{~N}$, giving them greater resistance to handling and transport. Pinto, Pinheiro Neto and Guimarães (2011) noted that distributors want cultivars with this feature. Firmness did not differ in the mature fruit, although the Van Dyke, Momi-K and Aplle DCG 406 had values of approximately $7 \mathrm{~N}$ (Table 1), which is characteristic of good firmness, according Montalvo et al. (2009).

Knowledge of the shelf life of fruits is essential to assess the need for the use of specific techniques of post-harvest conservation. The accessions under test varied as to the number of days of storage needed to ripen at room temperature, two groups being determined: 6-9 days and 10-13 days (Table 1). Fruits from accessions M-13269, Chené and Van Dyke were similar to the Tommy Atkins, displaying slower ripening.

The accessions Amrapali, Manila and Scuper Many, were characterised by the absence of fibre, while the Olour, Aplle DCG 406, Black Java, Chené, Manzanillo, Mon Amon, 65, Florigon, Irwin, Momi-K Maya and Winter had low fibre (Table 1). The fruits of the remaining accessions were characterised as fibrous. Pinto et al. (2005) stressed the importance of cultivars without fibres, which appeal to consumers.

Colour is a very important component of quality for the consumer, and should display uniformity and intensity. The Manila accession showed the greatest skin brightness for the two maturity stage (Table 2). According to Ribeiro et al. (2007), ripe fruit from the Haden, Tommy Atkins and Palmer accessions had a skin luminosity of $61.3,58.3$ and 54.9 respectively. For values of $\mathrm{C}$ in the skin, representing purity of colour, there were statistically significant differences between accessions, forming two groups for the physiologically mature fruit, which ranged from 18.05 in the Manzanillo to 31.08 in the Black Java (Table 2). The ripe fruit of the Momi-K accession had a markedly higher colour intensity (Table 2). For $\mathrm{H}$, the skin colour of the accessions at physiological maturity was characterised by variations from a yellowish green to yellow (Table 2). In the Tommy Atkins and Van Dyke accessions, skin colour, which was already yellow when harvested, turned orange when the fruits were ripe (Table 2). For the ripe mangoes, the predominant skin colour was yellow.

In the pulp, the Manila accession also had the highest average values for $\mathrm{L}$, both in fruits at physiological maturity (66.48) and when ripe $(49,06)$ (Table 2). The Zill and Mon Amon accessions showed more intense colour at physiological maturity (Table 2). However, the mature fruit 
of the Amrapali, Winter, Simmonds and Momi-K accessions had the highest averages (Table 2). The accessions already had a yellow-coloured pulp when harvested, but after maturing turned orange, with the strongest colour at both maturity stage being observed in the Haden, Simmonds, Winter Manila, Amrapali, Scuper Many, Maya, 65, Momi-K and Van Dyke (Table 2). According to Silva et al. (2011), at harvest time, the cultivar Ubá showed a greenish pulp in the region near the seeds. On the sixth day of storage however, the value for $\mathrm{H}$ was 93.90 , and by the end of the 42 days, these values went down to around 60.00 , characteristic of the orange colour of the pulp and similar to values found for most of the accessions tested in this study.

Table 1 - Average weight (AW), longitudinal diameter (LD), transverse diameter (TD), pulp firmness (PF), number of days for the completion of ripening (NR) and the presence of fibres, in fruits of mango accessions from the Active Germplasm Bank of Embrapa Semiárido, evaluated at two maturity stages (MS): physiological maturity (PM) and mature*

\begin{tabular}{|c|c|c|c|c|c|c|c|}
\hline Acession & MS & AW (g) & $\mathrm{LD}(\mathrm{mm})$ & $\mathrm{TD}(\mathrm{mm})$ & $\mathrm{PF}(\mathrm{N})$ & NR (days) & Fibre \\
\hline \multirow{2}{*}{ Olour } & PM & $245.10 \mathrm{D}$ & $96.69 \mathrm{D}$ & $74.09 \mathrm{D}$ & $63.06 \mathrm{~A}$ & \multirow{2}{*}{$6 \mathrm{~A}$} & \multirow{2}{*}{ Low } \\
\hline & Mature & $217.74 \mathrm{~b}$ & $94.41 \mathrm{c}$ & $61.22 \mathrm{~d}$ & $3.80 \mathrm{a}$ & & \\
\hline \multirow{2}{*}{ Amrapali } & PM & $144.35 \mathrm{~A}$ & $82.80 \mathrm{~A}$ & $59.01 \mathrm{~B}$ & $92.51 \mathrm{D}$ & \multirow{2}{*}{$8 \mathrm{~A}$} & \multirow{2}{*}{ Absent } \\
\hline & Mature & $136.49 \mathrm{a}$ & $81.92 \mathrm{a}$ & $49.38 \mathrm{a}$ & $3.38 \mathrm{a}$ & & \\
\hline \multirow{2}{*}{ Aplle DCG 406} & PM & $328.26 \mathrm{~F}$ & $98.26 \mathrm{D}$ & $84.32 \mathrm{E}$ & $117.94 \mathrm{G}$ & \multirow{2}{*}{$6 \mathrm{~A}$} & \multirow{2}{*}{ Low } \\
\hline & Mature & $287.83 \mathrm{~d}$ & $92.68 \mathrm{c}$ & $65.98 \mathrm{e}$ & $7.66 \mathrm{a}$ & & \\
\hline \multirow{2}{*}{ Black Java } & PM & $388.94 \mathrm{G}$ & $89.86 \mathrm{~B}$ & $81.44 \mathrm{E}$ & $97.37 \mathrm{E}$ & \multirow{2}{*}{$9 \mathrm{~A}$} & \multirow{2}{*}{ Low } \\
\hline & Mature & $281.36 \mathrm{~d}$ & $80.0 \mathrm{a}$ & $74.83 \mathrm{~g}$ & $6.95 \mathrm{a}$ & & \\
\hline \multirow{2}{*}{ Chené } & PM & $372.06 \mathrm{G}$ & $104.17 \mathrm{~F}$ & $75.58 \mathrm{D}$ & $106.16 \mathrm{~F}$ & \multirow{2}{*}{$11 \mathrm{~B}$} & \multirow{2}{*}{ Low } \\
\hline & Mature & $353.13 \mathrm{e}$ & $100.85 \mathrm{~d}$ & $71.89 \mathrm{f}$ & $1.43 \mathrm{a}$ & & \\
\hline \multirow{2}{*}{ Kensington } & PM & $299.25 \mathrm{E}$ & $87.20 \mathrm{~A}$ & $71.34 \mathrm{C}$ & $72.03 \mathrm{~B}$ & \multirow{2}{*}{$7 \mathrm{~A}$} & \multirow{2}{*}{ Fibrous } \\
\hline & Mature & $295.40 \mathrm{e}$ & $89.77 \mathrm{~b}$ & $69.08 \mathrm{f}$ & $2.79 \mathrm{a}$ & & \\
\hline \multirow{2}{*}{ Manila } & PM & $227.41 \mathrm{C}$ & $118.45 \mathrm{G}$ & $55.34 \mathrm{~A}$ & $72.06 \mathrm{~B}$ & \multirow{2}{*}{-} & \multirow{2}{*}{ Absent } \\
\hline & Mature & $205.05 \mathrm{~b}$ & $112.57 \mathrm{f}$ & $57.32 \mathrm{c}$ & $0.15 \mathrm{a}$ & & \\
\hline \multirow{2}{*}{ Manzanillo } & PM & $536.96 \mathrm{I}$ & $107.50 \mathrm{~F}$ & $98.79 \mathrm{G}$ & $89.58 \mathrm{D}$ & \multirow{2}{*}{$8 \mathrm{~A}$} & \multirow{2}{*}{ Low } \\
\hline & Mature & $528.13 \mathrm{~g}$ & 108.47 e & $83.72 \mathrm{i}$ & $6.67 \mathrm{a}$ & & \\
\hline \multirow{2}{*}{ Maya } & PM & $187.71 \mathrm{~B}$ & $93.73 \mathrm{C}$ & $56.27 \mathrm{~A}$ & $104.84 \mathrm{~F}$ & \multirow{2}{*}{$7 \mathrm{~A}$} & \multirow{2}{*}{ Low } \\
\hline & Mature & $172.67 \mathrm{a}$ & $92.82 \mathrm{c}$ & $53.64 \mathrm{~b}$ & $6.30 \mathrm{a}$ & & \\
\hline \multirow{2}{*}{ Mon Amon DCG 407} & PM & $327.15 \mathrm{~F}$ & $92.89 \mathrm{C}$ & $76.49 \mathrm{D}$ & $57.22 \mathrm{~A}$ & \multirow{2}{*}{$7 \mathrm{~A}$} & \multirow{2}{*}{ Low } \\
\hline & Mature & $297.48 \mathrm{~d}$ & $92.21 \mathrm{c}$ & $70.39 \mathrm{f}$ & $1.03 \mathrm{a}$ & & \\
\hline \multirow{2}{*}{ Tommy Atkins } & PM & $429.81 \mathrm{H}$ & $103.69 \mathrm{~F}$ & $90.07 \mathrm{~F}$ & $114.99 \mathrm{G}$ & & \\
\hline & Mature & $365.18 \mathrm{e}$ & $97.81 \mathrm{~d}$ & $78.76 \mathrm{~h}$ & $4.25 \mathrm{a}$ & & THeds \\
\hline 65 & PM & $381.51 \mathrm{G}$ & $91.03 \mathrm{~B}$ & $80.20 \mathrm{E}$ & $78.44 \mathrm{C}$ & $6 \hat{s}^{2}$ & J \\
\hline & Mature & $354.85 \mathrm{e}$ & $90.02 \mathrm{~b}$ & $75.18 \mathrm{~g}$ & $6.82 \mathrm{a}$ & & \\
\hline Florioon & $\mathrm{PM}$ & $293.68 \mathrm{E}$ & $100.01 \mathrm{E}$ & $69.01 \mathrm{C}$ & $86.56 \mathrm{D}$ & 84 & I \\
\hline & Mature & $265.65 \mathrm{c}$ & $98.65 \mathrm{~d}$ & $64.99 \mathrm{e}$ & $6.00 \mathrm{a}$ & & \\
\hline Haden & PM & $325.01 \mathrm{~F}$ & $90.47 \mathrm{~B}$ & $76.41 \mathrm{D}$ & $85.12 \mathrm{D}$ & $60^{-1}$ & \\
\hline & Mature & $399.83 \mathrm{f}$ & $100.52 \mathrm{~d}$ & $77.85 \mathrm{~h}$ & $5.91 \mathrm{a}$ & & \\
\hline
\end{tabular}


Continuation of Table 1

\begin{tabular}{|c|c|c|c|c|c|c|c|}
\hline \multirow{2}{*}{ Irwin } & $\mathrm{PM}$ & $285.90 \mathrm{E}$ & $92.49 \mathrm{C}$ & $71.38 \mathrm{C}$ & $75.22 \mathrm{~B}$ & \multirow{2}{*}{$7 \mathrm{~A}$} & \multirow{2}{*}{ Low } \\
\hline & Mature & $297.42 \mathrm{e}$ & $89.11 b$ & $69.96 \mathrm{f}$ & $4.21 \mathrm{a}$ & & \\
\hline \multirow{2}{*}{ M 13269} & PM & $207.66 \mathrm{C}$ & $101.01 \mathrm{E}$ & $60.62 \mathrm{~B}$ & $113.33 \mathrm{G}$ & \multirow{2}{*}{$10 \mathrm{~B}$} & \multirow{2}{*}{ Fibrous } \\
\hline & Mature & $193.91 \mathrm{~b}$ & $101.29 \mathrm{~d}$ & $57.54 \mathrm{c}$ & $5.02 \mathrm{a}$ & & \\
\hline \multirow{2}{*}{ Momi-K } & PM & $399.31 \mathrm{G}$ & $116.86 \mathrm{G}$ & $74.63 \mathrm{D}$ & $111.19 \mathrm{G}$ & \multirow{2}{*}{$6 \mathrm{~A}$} & \multirow{2}{*}{ Low } \\
\hline & Mature & $380.45 \mathrm{f}$ & $113.96 \mathrm{f}$ & $70.59 \mathrm{f}$ & $7.49 \mathrm{a}$ & & \\
\hline \multirow{2}{*}{ Scuper Many } & $\mathrm{PM}$ & $206.08 \mathrm{C}$ & $91.60 \mathrm{~B}$ & $60.64 \mathrm{~B}$ & $103.91 \mathrm{~F}$ & \multirow{2}{*}{$7 \mathrm{~A}$} & \multirow{2}{*}{ Absent } \\
\hline & Mature & $209.54 \mathrm{~b}$ & $91.89 \mathrm{c}$ & $58.26 \mathrm{c}$ & $6.71 \mathrm{a}$ & & \\
\hline \multirow{2}{*}{ Simmonds } & PM & $260.20 \mathrm{D}$ & 88.84 B & $68.32 \mathrm{C}$ & $82.21 \mathrm{C}$ & \multirow{2}{*}{$9 \mathrm{~A}$} & \multirow{2}{*}{ Fibrous } \\
\hline & Mature & $306.71 \mathrm{~d}$ & $95.33 \mathrm{c}$ & $69.94 \mathrm{f}$ & $5.02 \mathrm{a}$ & & \\
\hline \multirow{2}{*}{ Zill } & PM & $307.52 \mathrm{E}$ & $96.42 \mathrm{D}$ & $70.44 \mathrm{C}$ & $79.75 \mathrm{C}$ & \multirow{2}{*}{$8 \mathrm{~A}$} & \multirow{2}{*}{ Fibrous } \\
\hline & Mature & $315.58 \mathrm{~d}$ & $99.02 \mathrm{~d}$ & $67.23 \mathrm{e}$ & $5.32 \mathrm{a}$ & & \\
\hline \multirow{2}{*}{ Van Dyke } & $\mathrm{PM}$ & $235.38 \mathrm{D}$ & $90.42 \mathrm{~B}$ & $63.59 \mathrm{~B}$ & $123.58 \mathrm{H}$ & \multirow{2}{*}{$12 \mathrm{~B}$} & \multirow{2}{*}{ Fibrous } \\
\hline & Mature & $222.97 \mathrm{~b}$ & $88.55 \mathrm{~b}$ & $61.63 \mathrm{~d}$ & $6.97 \mathrm{a}$ & & \\
\hline \multirow{2}{*}{ Winter } & PM & $184.45 \mathrm{~B}$ & $86.19 \mathrm{~A}$ & $59.30 \mathrm{~B}$ & $122.49 \mathrm{H}$ & \multirow{2}{*}{$7 \mathrm{~A}$} & \multirow{2}{*}{ Low } \\
\hline & Mature & $158.95 \mathrm{a}$ & $80.12 \mathrm{a}$ & $54.71 \mathrm{~b}$ & $4.92 \mathrm{a}$ & & \\
\hline
\end{tabular}

*Averages followed by the same uppercase or lowercase letter in a column do not differ by Scott-Knott test $(p \leq 0.05)$

Table 2 - Luminosity (L) of the skin, chroma (C) of the skin, hue $(\mathrm{H})$ of the skin, $\mathrm{L}$ of the pulp, $\mathrm{C}$ of the pulp, $\mathrm{H}$ of the pulp in fruits of mango accessions from the Active Germplasm Bank of Embrapa Semiárido, evaluated at two maturity stages (MS): physiological maturity (PM) and mature*

\begin{tabular}{lccccccc}
\hline \multirow{2}{*}{ Acession } & MS & Skin L & Skin C & Skin H & Pulp L & Pulp C & Pulp H \\
\hline \multirow{2}{*}{ Olour } & PM & $45.18 \mathrm{D}$ & $30.01 \mathrm{~B}$ & $115.84 \mathrm{C}$ & $49.08 \mathrm{~B}$ & $17 \mathrm{~A}$ & $180.80 \mathrm{D}$ \\
& Mature & $48.51 \mathrm{c}$ & $29.04 \mathrm{~b}$ & $99.97 \mathrm{e}$ & $33.37 \mathrm{a}$ & $18.69 \mathrm{a}$ & $95.84 \mathrm{c}$ \\
\hline \multirow{2}{*}{ Amrapali } & PM & $39.14 \mathrm{C}$ & $28.22 \mathrm{~B}$ & $107.76 \mathrm{~B}$ & $53.99 \mathrm{C}$ & $31.79 \mathrm{D}$ & $91.53 \mathrm{~A}$ \\
& Mature & $38.24 \mathrm{a}$ & $22.96 \mathrm{a}$ & $101.03 \mathrm{e}$ & $40.27 \mathrm{~b}$ & $36.76 \mathrm{~d}$ & $77.94 \mathrm{a}$ \\
\hline \multirow{2}{*}{ Aplle DCG 406 } & PM & $40.69 \mathrm{C}$ & $24.16 \mathrm{~A}$ & $119.57 \mathrm{C}$ & $54.68 \mathrm{C}$ & $20.52 \mathrm{~A}$ & $104.46 \mathrm{C}$ \\
& Mature & $42.53 \mathrm{~b}$ & $26.35 \mathrm{a}$ & $103.16 \mathrm{e}$ & $39.14 \mathrm{~b}$ & $24.83 \mathrm{~b}$ & $83.28 \mathrm{~b}$ \\
\hline \multirow{2}{*}{ Black Java } & PM & $49.27 \mathrm{E}$ & $31.08 \mathrm{~B}$ & $109.40 \mathrm{~B}$ & $51.64 \mathrm{~B}$ & $24.36 \mathrm{C}$ & $102.13 \mathrm{C}$ \\
& Mature & $49.92 \mathrm{c}$ & $30.08 \mathrm{~b}$ & $86.59 \mathrm{c}$ & $39.08 \mathrm{~b}$ & $26.03 \mathrm{~b}$ & $89.83 \mathrm{c}$ \\
\hline \multirow{2}{*}{ Chené } & PM & $40.21 \mathrm{C}$ & $21.87 \mathrm{~A}$ & $123.49 \mathrm{C}$ & $54.89 \mathrm{C}$ & $21.67 \mathrm{~B}$ & $102.69 \mathrm{C}$ \\
& Mature & $47.03 \mathrm{c}$ & $34.85 \mathrm{~b}$ & $80.56 \mathrm{c}$ & $39.83 \mathrm{~b}$ & $27.51 \mathrm{~b}$ & $84.03 \mathrm{~b}$ \\
\hline \multirow{2}{*}{ Kensington } & PM & $35.82 \mathrm{~A}$ & $29.91 \mathrm{~B}$ & $108.29 \mathrm{~B}$ & $42.64 \mathrm{~A}$ & $27.13 \mathrm{C}$ & $93.38 \mathrm{~B}$ \\
& Mature & $44.79 \mathrm{~b}$ & $31.34 \mathrm{~b}$ & $92.46 \mathrm{~d}$ & $35.07 \mathrm{a}$ & $35.27 \mathrm{c}$ & $82.13 \mathrm{a}$ \\
\hline \multirow{2}{*}{ Manila } & PM & $60.50 \mathrm{~F}$ & $22.65 \mathrm{~A}$ & $104.94 \mathrm{~A}$ & $66.48 \mathrm{D}$ & $25.14 \mathrm{~B}$ & $88.94 \mathrm{~A}$ \\
& Mature & $58.35 \mathrm{~d}$ & $26.25 \mathrm{a}$ & $80.45 \mathrm{c}$ & $49.06 \mathrm{~d}$ & $23.71 \mathrm{~b}$ & $77.45 \mathrm{a}$ \\
\hline
\end{tabular}


Continuation of Table 2

\begin{tabular}{|c|c|c|c|c|c|c|c|}
\hline \multirow{2}{*}{ Manzanillo } & PM & $34.45 \mathrm{~A}$ & $18.05 \mathrm{~A}$ & $119.02 \mathrm{C}$ & $50.62 \mathrm{~B}$ & $22.63 \mathrm{~B}$ & $97.20 \mathrm{~B}$ \\
\hline & Mature & $39.75 \mathrm{a}$ & $24.97 \mathrm{a}$ & $76.26 \mathrm{~b}$ & $37.12 \mathrm{a}$ & $25.56 \mathrm{~b}$ & $84.08 \mathrm{a}$ \\
\hline \multirow{2}{*}{ Maya } & PM & $43.77 \mathrm{D}$ & $23.46 \mathrm{~A}$ & $120.14 \mathrm{C}$ & $47.65 \mathrm{~B}$ & $28.08 \mathrm{C}$ & $88.10 \mathrm{~A}$ \\
\hline & Mature & $50.13 c$ & $30.04 \mathrm{~b}$ & $84.86 \mathrm{c}$ & $35.88 \mathrm{a}$ & $25.27 b$ & $80.40 \mathrm{a}$ \\
\hline \multirow{2}{*}{ Mon Amon DCG 407} & PM & $45.42 \mathrm{D}$ & $25.17 \mathrm{~A}$ & $118.52 \mathrm{C}$ & $51.43 \mathrm{~B}$ & $38.76 \mathrm{E}$ & $95.18 \mathrm{~B}$ \\
\hline & Mature & $49.49 \mathrm{c}$ & $32.13 \mathrm{~b}$ & $95.36 \mathrm{~d}$ & $45.38 \mathrm{c}$ & $35.25 \mathrm{c}$ & $84.92 \mathrm{~b}$ \\
\hline \multirow{2}{*}{ Tommy Atkins } & $\mathrm{PM}$ & $38.26 \mathrm{~B}$ & $20.36 \mathrm{~A}$ & $99.31 \mathrm{~A}$ & $46.35 \mathrm{~A}$ & $24.18 \mathrm{~B}$ & $94.34 \mathrm{~B}$ \\
\hline & Mature & $39.98 \mathrm{a}$ & $24.96 \mathrm{a}$ & $70.37 \mathrm{a}$ & $37.82 \mathrm{~b}$ & $25.76 \mathrm{~b}$ & $86.55 \mathrm{~b}$ \\
\hline \multirow{2}{*}{65} & PM & $45.79 \mathrm{D}$ & $28.58 \mathrm{~B}$ & $110.77 \mathrm{~B}$ & $50.83 \mathrm{~B}$ & $26.46 \mathrm{C}$ & $87.99 \mathrm{~A}$ \\
\hline & Mature & $44.61 \mathrm{~b}$ & $29.74 \mathrm{a}$ & $93.65 \mathrm{~d}$ & $37.11 \mathrm{a}$ & $28.77 \mathrm{~b}$ & $80.47 \mathrm{a}$ \\
\hline \multirow{2}{*}{ Florigon } & PM & $41.16 \mathrm{C}$ & $25.47 \mathrm{~A}$ & $117.18 \mathrm{C}$ & $54.04 \mathrm{C}$ & $27.96 \mathrm{C}$ & $96.97 \mathrm{~B}$ \\
\hline & Mature & $48.11 \mathrm{c}$ & $26.97 \mathrm{a}$ & $84.77 \mathrm{c}$ & $40.52 \mathrm{~b}$ & $28.84 \mathrm{~b}$ & $86.19 b$ \\
\hline \multirow{2}{*}{ Haden } & $\mathrm{PM}$ & $40.83 \mathrm{C}$ & $22.74 \mathrm{~A}$ & $116.77 \mathrm{C}$ & $52.46 \mathrm{C}$ & $26.18 \mathrm{C}$ & $90.34 \mathrm{~A}$ \\
\hline & Mature & $46.98 \mathrm{c}$ & $30.72 \mathrm{a}$ & $82.76 \mathrm{c}$ & $35.40 \mathrm{a}$ & $29.12 \mathrm{~b}$ & $74.94 \mathrm{a}$ \\
\hline \multirow{2}{*}{ Irwin } & PM & $40.35 \mathrm{C}$ & $24.34 \mathrm{~A}$ & $115.37 \mathrm{C}$ & $49.53 \mathrm{~B}$ & $32.17 \mathrm{D}$ & $90.34 \mathrm{a}$ \\
\hline & Mature & $44.25 \mathrm{~b}$ & $26.04 \mathrm{a}$ & $85.14 \mathrm{c}$ & $39.72 \mathrm{~b}$ & $32.77 \mathrm{c}$ & $83.04 \mathrm{~b}$ \\
\hline \multirow{2}{*}{ M 13269} & PM & $44.96 \mathrm{D}$ & $28.36 \mathrm{~B}$ & $112.53 \mathrm{C}$ & $55.27 \mathrm{C}$ & $13.84 \mathrm{~A}$ & $111.65 \mathrm{D}$ \\
\hline & Mature & $48.85 \mathrm{c}$ & $31.03 \mathrm{a}$ & $87.40 \mathrm{c}$ & $36.08 \mathrm{a}$ & $26.43 \mathrm{~b}$ & $85.29 b$ \\
\hline \multirow{2}{*}{ Momi-K } & PM & $39.90 \mathrm{C}$ & $25.05 \mathrm{~A}$ & $116.83 \mathrm{C}$ & $55.53 \mathrm{C}$ & $30.68 \mathrm{D}$ & $86.03 \mathrm{~A}$ \\
\hline & Mature & $41.66 \mathrm{a}$ & $49.46 \mathrm{c}$ & $66.19 \mathrm{a}$ & $38.72 \mathrm{~b}$ & $39.93 \mathrm{~d}$ & $81.13 \mathrm{a}$ \\
\hline \multirow{2}{*}{ Scuper Many } & PM & $42.66 \mathrm{D}$ & $25.71 \mathrm{~A}$ & $116.39 \mathrm{C}$ & $42.89 \mathrm{~A}$ & $27.51 \mathrm{C}$ & $87.47 \mathrm{~A}$ \\
\hline & Mature & $48.98 \mathrm{c}$ & $30.27 \mathrm{a}$ & $85.54 \mathrm{c}$ & $32.97 \mathrm{a}$ & $31.99 \mathrm{c}$ & $78.16 \mathrm{a}$ \\
\hline \multirow{2}{*}{ Simmonds } & PM & $34.01 \mathrm{~A}$ & $24.46 \mathrm{~A}$ & $111.32 \mathrm{~B}$ & $48.37 \mathrm{~B}$ & $30.03 \mathrm{D}$ & $86.10 \mathrm{a}$ \\
\hline & Mature & $41.89 \mathrm{a}$ & $32.73 \mathrm{a}$ & $75.03 \mathrm{~b}$ & $36.70 \mathrm{a}$ & $39.83 \mathrm{~d}$ & $75.85 \mathrm{a}$ \\
\hline \multirow{2}{*}{ Zill } & PM & $34.11 \mathrm{~A}$ & $27.58 \mathrm{~B}$ & $113.45 \mathrm{C}$ & $44.89 \mathrm{~A}$ & $35.94 \mathrm{E}$ & $90.79 \mathrm{~A}$ \\
\hline & Mature & $43.47 \mathrm{~b}$ & $27.63 \mathrm{a}$ & $92.89 \mathrm{~d}$ & $35.61 \mathrm{a}$ & $31.51 \mathrm{c}$ & $82.75 b$ \\
\hline \multirow{2}{*}{ Van Dyke } & PM & $43.38 \mathrm{D}$ & $23.85 \mathrm{~A}$ & $105.48 \mathrm{~A}$ & $51.12 \mathrm{~B}$ & $24.30 \mathrm{~B}$ & $91.49 \mathrm{~A}$ \\
\hline & Mature & $44.64 \mathrm{~b}$ & $33.02 \mathrm{a}$ & $74.84 \mathrm{~b}$ & $35.08 \mathrm{a}$ & $28.31 \mathrm{~b}$ & $81.39 \mathrm{a}$ \\
\hline \multirow{2}{*}{ Winter } & $\mathrm{PM}$ & $42.34 \mathrm{C}$ & $25.99 \mathrm{~A}$ & $112.96 \mathrm{C}$ & $55.39 \mathrm{C}$ & $30.98 \mathrm{D}$ & $91.07 \mathrm{~A}$ \\
\hline & Mature & $50.04 \mathrm{c}$ & $31.05 \mathrm{a}$ & $79.17 \mathrm{c}$ & $36.85 \mathrm{a}$ & $37.58 \mathrm{~d}$ & $77.16 \mathrm{a}$ \\
\hline
\end{tabular}

*Averages followed by the same uppercase or lowercase letter in a column do not differ by Scott-Knott test $(p \leq 0.05)$

Titratable acidity is very important to the taste of mangoes due to the ratio of sugar to acidity. The fruits generally display a decrease in TA during ripening, however with the increase in carbon availability there is an increase in the sugar concentration (JOAS; CARO; LECHAUDEL, 2009). The TA of the fruit at physiological maturity ranged from 0.13 to $1.71 \%$ citric acid (Table 3 ), seen in the Oluor and M-13269 accessions respectively. Given that fruits with a better flavour are those with intermediate acidity, around $0.40 \%$ citric acid when ripe, the accessions Irwin, Florigon, Amon Mon, Momi-K, Black Java, Winter, Zill, M 13269 and Aplle DCG 406 
would all meet this supposition. Faraoni, Ramos and Stringheta (2009) reported that the Ubá cultivar when mature has a TA of $0.40 \%$ citric acid and is well accepted in the market.

The levels of SS in the fruits at physiological maturity ranged from 8.2 to $12.2^{\circ}$ Brix, seen in the $\mathrm{M}$ 13269 and Olour accessions respectively (Table 3). When ripe, the fruits of the Amrapali accession showed the highest levels of SS at $24.7^{\circ}$ Brix. It should be noted that after ripening, with the exception of the Chené, the other accessions showed an SS greater than that of the Tommy Atkins. As TSS are the main constituents of SS, accessions that showed the highest levels were also the Olour (10.5 g

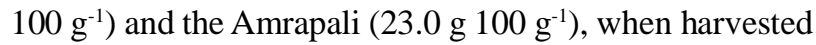
and when mature respectively (Table 3 ). In a study with the Ataulfo cultivar, Montalvo et al. (2009) found an increase of $17.47 \%$ in SS levels during storage. When characterising 39 mango cultivars from the Polo Apta
Centro-Norte collection in Sao Paulo, SS levels ranged from 24.9 to $12.5^{\circ}$ Brix for the Smith and Brazil cultivars respectively (GALLI et al., 2008).

The increase in SS content in the fruit during ripening is due mainly to the hydrolysis of reserve carbohydrates. In this study, the starch content at

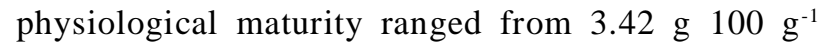

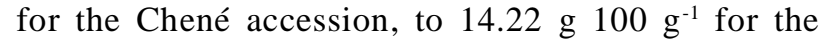
Manila, which was no different from the Amrapali (Table 3). In the mature fruit, there was no statistical difference for starch content (Table 3). According to Bernardes-Silva, Lajolo and Cordenunsi (2003), the pattern of starch degradation varies with the cultivar. Those authors stated that the levels of starch found are sources of carbon for the post-harvest synthesis of sucrose, despite there being a time lag in some cases between this degradation and accumulation of the sucrose.

Table 3 - Titratable acidity (TA), soluble solids (SS), total soluble sugars (TSS), reducing sugars (RS), starch, vitamin C (Vit. C) and total carotenoids (TC) in fruits of mango accessions from the Active Germplasm Bank of Embrapa Semiárido, evaluated at two maturity stages (MS): physiological maturity (PM) and mature*

\begin{tabular}{|c|c|c|c|c|c|c|c|c|}
\hline \multirow{2}{*}{ Accession } & \multirow{2}{*}{ MS } & TA & SS & TSS & RS & Starch & Vit. C & \multirow{2}{*}{$\frac{\mathrm{TC}}{\left(\mathrm{mg} .100 \mathrm{~g}^{-1}\right)}$} \\
\hline & & (\% citric acid) & $\left({ }^{\circ} \mathrm{Brix}\right)$ & \multicolumn{2}{|c|}{$\left(\mathrm{g} .100 \mathrm{~g}^{-1}\right)$} & \multicolumn{2}{|c|}{$\left(\mathrm{mg} .100 \mathrm{~mL}^{-1}\right)$} & \\
\hline \multirow{2}{*}{ Olour } & PM & $0.13 \mathrm{~A}$ & $12.20 \mathrm{C}$ & $10.54 \mathrm{C}$ & $6.65 \mathrm{H}$ & $3.69 \mathrm{~A}$ & $53.86 \mathrm{~B}$ & $0.80 \mathrm{~B}$ \\
\hline & Mature & $0.19 \mathrm{a}$ & $20.73 \mathrm{e}$ & $17.43 \mathrm{~b}$ & $7.06 \mathrm{f}$ & $0.25 \mathrm{a}$ & $49.00 \mathrm{~b}$ & $0.38 \mathrm{a}$ \\
\hline \multirow{2}{*}{ Amrapali } & $\mathrm{PM}$ & $1.53 \mathrm{E}$ & $11.40 \mathrm{C}$ & $7.43 \mathrm{~A}$ & $3.38 \mathrm{~B}$ & $13.26 \mathrm{E}$ & $96.33 \mathrm{~F}$ & $0.80 \mathrm{~B}$ \\
\hline & Mature & $0.21 \mathrm{a}$ & $24.67 \mathrm{~g}$ & $23.03 \mathrm{e}$ & $4.47 \mathrm{c}$ & $0.14 \mathrm{a}$ & $50.58 \mathrm{~b}$ & $2.30 \mathrm{~d}$ \\
\hline \multirow{2}{*}{ Aplle DCG 406} & $\mathrm{PM}$ & $0.53 \mathrm{~B}$ & $9.07 \mathrm{~A}$ & $7.07 \mathrm{~A}$ & $4.85 \mathrm{E}$ & $4.36 \mathrm{~A}$ & $75.13 \mathrm{D}$ & $0.80 \mathrm{~B}$ \\
\hline & Mature & $0.48 \mathrm{~b}$ & $19.53 \mathrm{~d}$ & $14.76 \mathrm{a}$ & $5.57 \mathrm{~d}$ & $0.22 \mathrm{a}$ & $53.85 \mathrm{~b}$ & $0.53 \mathrm{a}$ \\
\hline \multirow{2}{*}{ Black Java } & PM & $1.25 \mathrm{D}$ & $9.20 \mathrm{~A}$ & $6.10 \mathrm{~A}$ & $3.60 \mathrm{~B}$ & $7.36 \mathrm{C}$ & $44.08 \mathrm{~A}$ & $0.80 \mathrm{~B}$ \\
\hline & Mature & $0.40 \mathrm{~b}$ & $18.37 \mathrm{c}$ & $14.25 \mathrm{a}$ & $5.56 \mathrm{~d}$ & $0.25 \mathrm{a}$ & $53.87 \mathrm{~b}$ & $0.38 \mathrm{a}$ \\
\hline \multirow{2}{*}{ Chené } & $\mathrm{PM}$ & $0.87 \mathrm{C}$ & $8.80 \mathrm{~A}$ & $5.90 \mathrm{~A}$ & $3.86 \mathrm{C}$ & $3.42 \mathrm{~A}$ & $78.35 \mathrm{D}$ & $0.80 \mathrm{~B}$ \\
\hline & Mature & $0.17 \mathrm{a}$ & $15.47 \mathrm{a}$ & $13.12 \mathrm{a}$ & $3.39 \mathrm{a}$ & $0.12 \mathrm{a}$ & $55.53 \mathrm{~b}$ & $0.83 \mathrm{a}$ \\
\hline \multirow{2}{*}{ Kensington } & $\mathrm{PM}$ & $1.21 \mathrm{D}$ & $11.23 \mathrm{C}$ & $7.97 \mathrm{~B}$ & $4.74 \mathrm{E}$ & $5.01 \mathrm{~A}$ & $53.89 \mathrm{~B}$ & $0.27 \mathrm{~A}$ \\
\hline & Mature & $0.28 \mathrm{a}$ & $19.07 \mathrm{~d}$ & $16.51 \mathrm{~b}$ & $4.74 \mathrm{c}$ & $0.12 \mathrm{a}$ & $40.82 \mathrm{a}$ & $0.63 \mathrm{a}$ \\
\hline \multirow{2}{*}{ Manila } & PM & $1.55 \mathrm{E}$ & $10.07 \mathrm{~A}$ & $8.07 \mathrm{~B}$ & $6.23 \mathrm{G}$ & $14.22 \mathrm{E}$ & $63.67 \mathrm{C}$ & $0.70 \mathrm{~B}$ \\
\hline & Mature & $0.16 \mathrm{a}$ & $21.87 \mathrm{e}$ & $20.49 \mathrm{~d}$ & $4.02 \mathrm{~b}$ & $0.13 \mathrm{a}$ & $50.62 \mathrm{~b}$ & $0.55 \mathrm{a}$ \\
\hline \multirow{2}{*}{ Manzanillo } & PM & $0.99 \mathrm{D}$ & $9.60 \mathrm{~A}$ & $6.70 \mathrm{~A}$ & $4.08 \mathrm{C}$ & $4.29 \mathrm{~A}$ & $52.25 \mathrm{~B}$ & $0.23 \mathrm{~A}$ \\
\hline & Mature & $0.77 \mathrm{c}$ & $17.57 \mathrm{c}$ & $15.92 \mathrm{~b}$ & $5.58 \mathrm{~d}$ & $0.13 \mathrm{a}$ & $53.86 \mathrm{~b}$ & $0.78 \mathrm{a}$ \\
\hline \multirow{2}{*}{ Maya } & PM & $0.40 \mathrm{~B}$ & $11.20 \mathrm{C}$ & $8.87 \mathrm{~B}$ & $7.13 \mathrm{I}$ & $6.66 \mathrm{~B}$ & $58.75 \mathrm{~B}$ & $0.18 \mathrm{~A}$ \\
\hline & Mature & $0.31 \mathrm{a}$ & $19.93 \mathrm{~d}$ & $17.24 \mathrm{~b}$ & $4.24 \mathrm{~b}$ & $0.73 \mathrm{a}$ & $52.22 \mathrm{~b}$ & $1.17 \mathrm{~b}$ \\
\hline
\end{tabular}


Continuation of Table 3

\begin{tabular}{|c|c|c|c|c|c|c|c|c|}
\hline \multirow{2}{*}{ Mon Amon DCG 407} & $\mathrm{PM}$ & $1.43 \mathrm{E}$ & $9.47 \mathrm{~A}$ & $6.82 \mathrm{~A}$ & $2.48 \mathrm{~A}$ & $9.03 \mathrm{D}$ & $75.09 \mathrm{D}$ & $0.44 \mathrm{~A}$ \\
\hline & Mature & $0.39 \mathrm{~b}$ & $22.67 \mathrm{f}$ & $18.50 \mathrm{c}$ & $4.92 \mathrm{c}$ & $0.38 \mathrm{a}$ & $73.43 \mathrm{c}$ & $1.66 \mathrm{c}$ \\
\hline \multirow{2}{*}{ Tommy Atkins } & PM & $0.60 \mathrm{~B}$ & $8.63 \mathrm{~A}$ & $6.46 \mathrm{~A}$ & $4.30 \mathrm{D}$ & $4.94 \mathrm{~A}$ & $40.82 \mathrm{~A}$ & $0.58 \mathrm{~B}$ \\
\hline & Mature & $0.17 \mathrm{a}$ & $16.97 \mathrm{~b}$ & $15.22 \mathrm{a}$ & $3.55 \mathrm{a}$ & $0.12 \mathrm{a}$ & $50.60 \mathrm{~b}$ & $1.28 \mathrm{~b}$ \\
\hline \multirow{2}{*}{65} & $\mathrm{PM}$ & $1.12 \mathrm{D}$ & $10.33 \mathrm{~B}$ & $7.46 \mathrm{~A}$ & $3.46 \mathrm{~B}$ & $5.89 \mathrm{~B}$ & $58.79 \mathrm{~B}$ & $0.48 \mathrm{~B}$ \\
\hline & Mature & $0.62 \mathrm{c}$ & $18.50 \mathrm{c}$ & $14.27 \mathrm{a}$ & $4.82 \mathrm{c}$ & $0.26 \mathrm{a}$ & $37.54 \mathrm{a}$ & $0.65 \mathrm{a}$ \\
\hline \multirow{2}{*}{ Florigon } & $\mathrm{PM}$ & $0.56 \mathrm{~B}$ & $10.30 \mathrm{~B}$ & $8.40 \mathrm{~B}$ & $4.32 \mathrm{D}$ & $4.27 \mathrm{~A}$ & $52.24 \mathrm{~B}$ & $0.39 \mathrm{~A}$ \\
\hline & Mature & $0.37 \mathrm{~b}$ & $17.60 \mathrm{c}$ & $14.99 \mathrm{a}$ & $5.89 \mathrm{e}$ & $0.25 \mathrm{a}$ & $65.32 \mathrm{c}$ & $0.49 \mathrm{a}$ \\
\hline \multirow{2}{*}{ Haden } & $\mathrm{PM}$ & $0.95 \mathrm{D}$ & $9.17 \mathrm{~A}$ & $6.87 \mathrm{~A}$ & $3.29 \mathrm{~B}$ & $5.42 \mathrm{~A}$ & $47.94 \mathrm{~A}$ & $0.52 \mathrm{~B}$ \\
\hline & Mature & $0.29 \mathrm{a}$ & $19.97 \mathrm{~d}$ & $18.56 \mathrm{c}$ & $4.08 \mathrm{~b}$ & $0.24 \mathrm{a}$ & $42.44 \mathrm{a}$ & $1.25 \mathrm{~b}$ \\
\hline \multirow{2}{*}{ Irwin } & $\mathrm{PM}$ & $0.96 \mathrm{C}$ & $10.33 \mathrm{~B}$ & $7.47 \mathrm{~A}$ & $4.26 \mathrm{D}$ & $7.62 \mathrm{C}$ & $35.91 \mathrm{~A}$ & $0.21 \mathrm{~A}$ \\
\hline & Mature & $0.37 \mathrm{~b}$ & $21.87 \mathrm{e}$ & $19.87 \mathrm{~d}$ & $4.99 \mathrm{c}$ & $0.25 \mathrm{a}$ & $34.28 \mathrm{a}$ & $1.02 \mathrm{~b}$ \\
\hline \multirow{2}{*}{ M 13269} & $\mathrm{PM}$ & $1.71 \mathrm{E}$ & $8.23 \mathrm{~A}$ & $5.44 \mathrm{~A}$ & $2.79 \mathrm{~A}$ & $9.19 \mathrm{D}$ & $76.75 \mathrm{D}$ & - \\
\hline & Mature & $0.45 \mathrm{~b}$ & $18.27 \mathrm{c}$ & $14.67 \mathrm{a}$ & $3.85 \mathrm{~b}$ & $1.02 \mathrm{a}$ & $63.65 \mathrm{c}$ & $0.73 \mathrm{a}$ \\
\hline \multirow{2}{*}{ Momi-K } & $\mathrm{PM}$ & $1.47 \mathrm{E}$ & $8.83 \mathrm{~A}$ & $5.58 \mathrm{~A}$ & $3.59 \mathrm{~B}$ & $5.05 \mathrm{~A}$ & $44.07 \mathrm{~A}$ & $0.42 \mathrm{~A}$ \\
\hline & Mature & $0.40 \mathrm{~b}$ & $20.23 \mathrm{~d}$ & $16.77 \mathrm{~b}$ & $5.27 \mathrm{~d}$ & $0.48 \mathrm{a}$ & $47.36 \mathrm{~b}$ & $1.06 \mathrm{~b}$ \\
\hline \multirow{2}{*}{ Scuper Many } & $\mathrm{PM}$ & $0.40 \mathrm{~B}$ & $9.33 \mathrm{~A}$ & $7.60 \mathrm{~A}$ & $6.05 \mathrm{G}$ & $8.50 \mathrm{D}$ & $65.30 \mathrm{C}$ & $0.16 \mathrm{~A}$ \\
\hline & Mature & $0.29 \mathrm{a}$ & $21.27 \mathrm{e}$ & $18.11 \mathrm{c}$ & $7.36 \mathrm{f}$ & $0.27 \mathrm{a}$ & $48.98 \mathrm{~b}$ & $1.03 \mathrm{~b}$ \\
\hline \multirow{2}{*}{ Simmonds } & $\mathrm{PM}$ & $1.19 \mathrm{D}$ & $11.60 \mathrm{C}$ & $8.47 \mathrm{~B}$ & $5.65 \mathrm{~F}$ & $4.75 \mathrm{~A}$ & $45.71 \mathrm{~A}$ & $0.22 \mathrm{~A}$ \\
\hline & Mature & $0.17 \mathrm{a}$ & $20.13 \mathrm{~d}$ & $15.87 \mathrm{~b}$ & $3.78 \mathrm{~b}$ & $0.37 \mathrm{a}$ & $37.57 \mathrm{a}$ & $1.39 \mathrm{c}$ \\
\hline \multirow{2}{*}{ Zill } & $\mathrm{PM}$ & $1.13 \mathrm{D}$ & $10.40 \mathrm{~B}$ & $7.27 \mathrm{~A}$ & $3.71 \mathrm{~B}$ & $4.63 \mathrm{~A}$ & $45.70 \mathrm{~A}$ & $0.50 \mathrm{~B}$ \\
\hline & Mature & $0.42 \mathrm{~b}$ & $19.83 \mathrm{~d}$ & $15.94 \mathrm{~b}$ & $4.89 \mathrm{c}$ & $0.76 \mathrm{a}$ & $37.56 \mathrm{a}$ & $1.06 \mathrm{~b}$ \\
\hline \multirow{2}{*}{ Van Dyke } & PM & $1.27 \mathrm{D}$ & $8.63 \mathrm{~A}$ & $6.53 \mathrm{~A}$ & $4.39 \mathrm{D}$ & $6.11 \mathrm{~B}$ & $48.96 \mathrm{~A}$ & $0.51 \mathrm{~B}$ \\
\hline & Mature & $0.32 \mathrm{a}$ & $18.60 \mathrm{c}$ & $15.11 \mathrm{a}$ & $4.05 \mathrm{~b}$ & $0.29 \mathrm{a}$ & $47.34 \mathrm{~b}$ & $1.42 \mathrm{c}$ \\
\hline \multirow{2}{*}{ Winter } & $\mathrm{PM}$ & $1.70 \mathrm{E}$ & $9.96 \mathrm{~B}$ & $6.62 \mathrm{~A}$ & $3.92 \mathrm{C}$ & $7.37 \mathrm{C}$ & $83.23 \mathrm{E}$ & $0.59 \mathrm{~B}$ \\
\hline & Mature & $0.42 \mathrm{~b}$ & $23.10 \mathrm{f}$ & $16.98 \mathrm{~b}$ & $3.98 \mathrm{~b}$ & $0.15 \mathrm{a}$ & $47.36 \mathrm{~b}$ & $1.51 \mathrm{c}$ \\
\hline
\end{tabular}

*Averages followed by the same uppercase or lowercase letter in a column do not differ by Scott-Knott test ( $p \leq 0.05)$

The accessions that showed the highest levels of reducing sugars at the two different maturity stages (MS) were the Olour and Scuper Many (Table 3). After ripening, the accessions Chené, Manila, Manzanillo, Tommy Atkins, Simmonds and Van Dyke displayed little change in the levels of reducing sugars. Whereas the Maya accession suffered a sharp decline, going

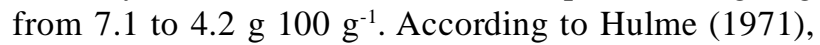
this is possibly due to most of the sugars being reducing sugars (fructose and glucose) at the start of maturation, however by the end of the process, non-reducing sugars predominate. As such, there is a change in the quality of the sugars but not in the quantity.
Vitamin $\mathrm{C}$ is degraded at ripening, so values tend to decrease in the mature fruit. In fruits of the Chené, 65, Winter and Amrapali accessions, this reduction was more pronounced (Table 3). The latter accession showed the highest ascorbic acid content at harvest. In the mature fruit, the highest levels of vitamin $\mathrm{C}$ were 73.43, 65.32 and $63.65 \mathrm{mg} 100 \mathrm{~mL}^{-1}$, seen in the Mon Amon, Florigon and M-13269 accessions respectively (Table 3). Such levels are relatively good when compared to cultivars that excel due to their high levels of

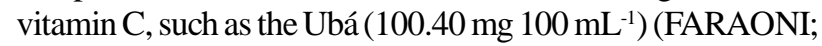
RAMOS; STRINGHETA, 2009). In this study, the vitamin C content of the ripe fruit of the Tommy Atkins accession was $50.60 \mathrm{mg} 100 \mathrm{~mL}^{-1}$, more than that observed in fruits of the 
same cultivar produced in the state of São Paulo, which had levels of $39.00 \mathrm{mg} 100 \mathrm{~mL}^{-1}$ (BOMFIM et al., 2011). These differences are related to the maturity stages (MS), growing conditions and climate, among other factors.

For the carotenoids content, the formation of two groups was seen during physiological maturity, with the group that showed higher levels ranging from 0.49 to $0.80 \mathrm{mg} 100 \mathrm{~g}^{-1}$, corresponding to the 65 and Aplle DCG 406 accessions respectively (Table 3 ). During maturation, there was an increase in the carotenoids content, explained by the synthesis and exposure of pre-existing pigments in the tissue. In the ripe fruit, the Amrapali accession stood out for its higher average of $2.3 \mathrm{mg} 100 \mathrm{~g}^{-1}$, followed by the Simmonds, Van Dyke, Winter and Mon Amon (Table 3). A similar result was seen in Haden mangoes, which

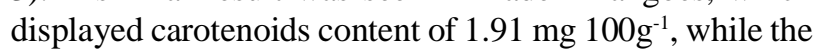
values found for the Tommy Atkins mangoes were higher (2.53 mg $100 \mathrm{~g}^{-1}$ ) (RIBEIRO et al., 2007).

\section{CONCLUSIONS}

1. The Chené accession stood out as to weight, size, ascorbic acid content, low fibre content and good postharvest conservation. The accession Momi-K, added greater firmness to the other characteristics, although it does not have good post-harvest conservation. The Van Dyke accession may represent an important source of the latter characteristic;

2. The Amrapali accession united those characteristics for quality which are consistent with the requirements of most markets, such as pulp with no fibre, high levels of starch and ascorbic acid when harvested, and high levels of SS, AST and carotenoids in the ripe fruit.

\section{REFERENCES}

ASSOCIATION OF OFFICIAL ANALYTICAL CHEMISTS. Official methods of analysis. 16 ed. Washington, 1998.

BANZATTO, D. A.; KRONKA, S. N. Experimentação agrícola. 4 ed. Funep: Jaboticabal, 2006. 237 p.

BERNARDES-SILVA,A.P.F.;LAJOLO,F.M.;CORDENUNSI, B. R. Evolução dos teores de amido e açúcares solúveis durante o desenvolvimento e amadurecimento de diferentes cultivares de manga. Ciência e Tecnologia de Alimentos, v. 23, p. 116120, 2003. Suplemento.

BRECHT, J. K.; YAHIA, E. M. Postharvest Physiology. In: LITZ, R. (Ed.). The Mango, botany, production and uses. 2nd ed. Wallingford: CAB, 2009. 680 p.

BOMFIM, M. P. et al.. Conservação pós-colheita de manga 'Tommy Atkins' com 1-metilciclopropeno. Revista Brasileira de Fruticultura, volume especial, p. 290-297, 2011.
FARAONI, A. S.; RAMOS, A. M.; STRINGHETA, P. C. caracterização da manga orgânica cultivar Ubá. Revista Brasileira de Produtos Agroindustriais, v. 11, n. 1, p. 9-14, 2009.

GALLI, J. A. et al. Qualidade de mangas cultivadas no Estado de São Paulo. Bragantia, v. 67, n. 3, p. 791-797, 2008.

HULME, A. C. The mango. In: HULME, A. C. The biochemistry of fruits and their products. New York: Academic Press, 1971. v. 2 , cap. 6 , p. 233-254.

INSTITUTO BRASILEIRO DE FRUTAS. Comparativo das exportações brasileiras de frutas frescas. 2011. Disponível em: <http://www.ibraf.org.br/estatisticas/est_frutas.asp>. Acesso em: 24 nov. 2011.

JOAS, J.; CARO, Y.; LECHAUDEL, M. Comparison of postharvest changes in mango (cv Cogshall) using a Ripening class index (Rci) for different carbon supplies and harvest dates. Postharvest Biology and Technology, v. 54, n. 1, p. 25-31, 2009.

MILLER, G. L. Use of dinitrosalicylic acid reagent for determination of reducing sugars. Analytical Chemistry, v. 31, n. 3, p. 426-428, 1959.

MONTALVO, E. et al. Changes of sugars, b-carotene and firmness of refrigerated Ataulfo mangoes treated with exogenous ethylene. Journal of Agricultural Science, v. 147, n. 2, p. 193-199, 2009.

PINTO, A. C. de Q. et al. Melhoramento genético. In: GENÚ, P. J. de C.; PINTO, A. C. de Q. (Ed.). A cultura da mangueira. Brasília, DF: Embrapa Informações Tecnológicas, 2002. p. 51-92.

PINTO, A. C. de Q. et al. Programa de melhoramento genético da manga e a nova cultivar BRS Ômega para o cerrado brasileiro. Planaltina-DF: Embrapa Comunicado Técnico 117, 2005. p. 1-8.

PINTO, A. C. de Q.; PINHEIRO NETO, F.; GUIMARÃES, T. G. Estratégias do melhoramento genético da manga a visando atender a dinâmica de mercado. Revista Brasileira de Fruticultura, v. 33, p. 64-72, 2011. Número Especial.

RIBEIRO, S. M. R. et al. Antioxidant in mango (Mangifera indica L.) pulp. Plant Foods for Human Nutrition, v. 62, n. 1, p. 13-17, 2007.

RIBEIRO, T. P. et al. Uso de revestimentos à base de dextrina na conservação pós-colheita de manga 'Tommy Atkins'. Revista Brasileira de Fruticultura, v. 31, n. 2, p. 343-351, 2009.

RUFINI, J.C. M. et al. Caracterização biométrica efísico-química dos frutos de acessos de manga 'Ubá'. Revista Brasileira de Fruticultura, v. 33, n. 2, p. 456-464, 2011.

SILVA, D. F. P. et al. Anticipation of 'ubá' mango ripening with preharvest ethephon application. Ciência Rural, v. 41, n. 1 , p. 63-69, 2011

VALEXPORT. Associação dos produtores e exportadores de hortifrutigranjeiros e derivados do Vale do São Francisco. Brazilian fruit. 2011. Disponível em: <http:// www.brazilianfruit.org/Pbr/Inteligencia/Estatisticas/PDF/ ExportaoBrasileiradeFrutasFrescasporEstados-Totais.pdf>. Acesso em: 24 nov. 2011.

YEMN, E. W.; WILLIS, A. J. The estimation of carbohydrate in plant extracts by anthrone. The Biochemical Journal, v. 57, n. 2, p. 504-514, 1954. 